\title{
CONSTITUTIONAL PATERNALISM: THE RISE AND \\ PROBLEMATIC USE OF CONSTITUTIONAL GUARDIAN RHETORIC
}

\author{
Brian Christopher Jones*
}

I. Introduction . . . . . . . . . . . . . . . . . . 774

II. Rise of the Guardian Language ........... 778

$\mathbf{R}$

A. Written Constitutions Using Guardian

Language ......................... 782

B. Legal Judgments Using Guardian Language .... 788

C. Law Journal and News Articles Using Guardian Language ......................... 792

III. The Significance of the Constitutional

Guardian Language ................... 794

A. The Judiciary's Use of Unnecessarily Factional

Language ......................... 795

B. The Judiciary's Overly Paternalistic

Understanding of Guardianship ............ 801

IV. Conclusion ............................ 805

This article examines the origins and use of constitutional guardian language, contending that the use of such language-which is now employed primarily in relation to the judiciary-is overly paternalistic and encounters both normative and consequentialist difficulties. The piece first attempts to determine when guardian language first arose, and when it took hold. It surveys the use of such language in written constitutions, judicial decisions, legal scholarship, and news reports, finding that the use of such guardianship language primarily emerged within the last two-to-three decades, although its use varies among platforms. The second half of the piece discusses why using such language matters, arguing that the use of guardian language is unnecessarily factional and dissuades other constitutional actors from participating in constitutional maintenance and protection. Also, the judiciary's understanding of guardian may take a more legal form as opposed to a general protecting and defending attitude, thus displaying the development of constitutional paternalism that is evident in many jurisdictions. Ultimately, the piece concludes that the judiciary serves a crucial constitutional role, but does not possess the exclusive right to assert constitutional guardianship status.

* Lecturer in Law, Dundee Law School, University of Dundee. Many thanks to Colin Reid for comments on an earlier version of this paper. Also thanks to my panel at the 2018 World Congress on Constitutional Law (WCCL) in Seoul, South Korea, and especially the chairs: Andras Jakob and Adrienne Stone. 


\section{INTRODUCTION}

It is common to speak of the judiciary as part of the system of checks and balances which contains and constrains the power of the Government; or as one of the three principle institutions of the State, each of which acts to limit the powers of the other two. The image has a pleasing and mechanistic appearance suggesting some objective hidden hand which holds the constitution in perpetual equilibrium. The extent to which the image reflects reality is less obvious.

$$
\text { - John Griffith }{ }^{1}
$$

In constitutional systems the world over, finding a label that rises above the lofty heights of constitutional guardian is difficult. Although diverse in application, this description implies that whoever attains such status also bears ultimate responsibility for the care and maintenance of the state's most important legal and political principles. Today scholars, practitioners, and even judges themselves laud judiciaries as the constitutional guardians of their respective jurisdictions. ${ }^{2}$ However, there are significant questions as to when this language emerged and what impact it may have on various constitutional settlements. This article examines the use and implications of constitutional guardian rhetoric. It does so by analysing when and where the constitutional guardian language arose and took hold, as well as why such language matters. Regarding the latter, this article maintains that the use of this language is factional, overly paternalistic, and dissuades other state actors-especially citizens-from participating in constitutional guardianship. After all, the protection and health of a constitutional state is a collective endeavour, and is not limited to one particular person or branch-regardless of what unique powers they may possess. Nevertheless, by most accounts investigated below, such constitutional guardian language is increasing, with the vast majority of references indi-

1. J. A. G. Griffith, The Politics of the Judiciary 335 (5th ed. 1997).

2. See, e.g., Judges as Guardians of Constitutionalism and Human Rights (Martin Scheinin et al. eds., 2016) (collection based on the role of national and supra-national judges and how they perform particular guardianship roles). As discussed below, when it comes to written constitutional text, identifying judges as guardians of constitutionalism and human rights is one prominent way in which judiciaries are portrayed nowadays. 
cating the judiciary as the anointed guardians. Although the use of such language has become commonplace over the past few decades, none have fully considered the effects of such language on the constitutional state.

In various times and places throughout history, scholars have debated which actor or actors constitute the ultimate constitutional guardians in particular states, ${ }^{3}$ but the idea is quite new in some common law jurisdictions where the judiciary has not played a dominant role. For example, the United Kingdom does not have a codified constitution, New Zealand possesses only a statutory constitution and bill of rights, and Australia has a written constitution but no bill of rights. While the judiciary in the United States has played a major role throughout the nation's history, much recent constitutional scholarship focuses on constitutionalism outside the courts, or even discusses taking the constitution away from the courts. ${ }^{4}$ Nevertheless, within the United Kingdom there remains consistent talk of drafting a written constitution. ${ }^{5}$ No doubt constitutional guardianship language would increase if this happened, as U.K. citizens would be increasingly forced to think in constitutional, as opposed to ordinary legal and political, terms.

Indeed, the United Kingdom is a good example of increasing guardianship language in regards to the judiciarydespite the comparatively high constraints in comparison with

3. See infra Part II. But see The Guardian of the Constitution: Hans Kelsen and Carl Schmitt on the Limits of Constitutional Law (Lars Vinx ed., trans., 2015) (book examining the back and forth between Kelsen and Schmitt about who the ultimate guardians are in the German Weimar Republic).

4. See, e.g., Mark Tushnet, Taking the Constitution Away from the Courts 194 (1999) (arguing that the United States should revert to a form of "populist constitutional[ism]," where not the Supreme Court, but "the public generally should participate in shaping constitutional law more directly and openly.”).

5. This arose primarily around the eight hundredth anniversary of the Magna Carta. See, e.g., Robert Blackburn, Enacting a Written Constitution for the United Kingdom, 36 Statute L. Rev. 1, 1-3 (2015) (noting that "political and social developments in the past few years have made the subject of the constitution a more relevant and topical subject in public affairs and opinion."). However, after the referendum outcome regarding the UK's decision to leave the EU, some have advocated it as a means of entrenching constitutional values, such as EU membership. Vernon Bogdanor, Beyond Brexit: Towards a British Constitution (2019). 
other jurisdictions. The quote by John Griffith that begins this piece was last published in 1997, just one year before the U.K. Parliament enacted the Human Rights Act (HRA) 1998. Although it is now impossible, as Professor Griffith has since passed away, it would be interesting to see if he still held this view. The HRA has become increasingly engrained over the past few decades, and beyond this, the United Kingdom established a new Supreme Court (UKSC). Granted, the UKSC isat least in theory-a mirror of the former Law Lords. Accordingly, the UKSC does not contain all the trappings of a normal supreme or constitutional court, especially in the sense that they cannot strike down primary legislation passed by the Westminster Parliament. ${ }^{6}$ Nevertheless, the courts can now make declarations of incompatibility under the HRA, ${ }^{7}$ and a number of rulings over the last two decades portray the U.K. judiciary as not merely the servant of a sovereign Parliament, but as the protector of certain constitutional values, such as the rule of law. ${ }^{8}$ Still, even with the HRA and the subsequent developments, suggesting that the U.K. judiciary are guardians of the constitution may be a stretch, especially given the significant amount of other actors within the United Kingdom that perform essential, and crucial, constitutional functions. ${ }^{9}$

Although the United Kingdom maintains an unwritten constitution, it is not immune from the use of guardian-esque language, especially as the prospect of a codified constitution continues to grow. ${ }^{10}$ Lady Hale, president of the U.K. Su-

6. Anthony Bradley, Keith Ewing \& Christopher Knight, ConstituTIONAL \& Administrative LAw (17th ed) (2018), 59-61.

7. Human Rights Act 1998, c. 42, § 4. Aileen Kavanagh even argues that, post-HRA 1998, UK judicial review can no longer be classified as "weak." See generally Aileen Kavanagh, What's So Weak About "Weak-form Review"? The Case of the Human Rights Act 1998, 13 InT'L J. Const. L. 1008 (2015).

8. See R. (on the application of Evans) v. Attorney General [2015] UKSC 21 (appeal taken from Eng.) (court ruled that the way the "executive override" located in s 53 of the Freedom of Information Act 2000 was used violated the rule of law); R. (on the application of UNISON) v. Lord Chancellor [2017] UKSC 51 (appeal taken from Eng.) (finding that fees orders prevented access to justice, which is a component of the rule of law).

9. Brian Christopher Jones, Our Forgotten Constitutional Guardians: Preserving Our Respect for Law, 10-12 (unpublished manuscript) (on file with author).

10. Such a document was proposed in Scotland before their 2014 independence referendum, and there have been a number of calls for a UK-wide document after the vote to leave the EU. Scottish Government, Scottish In- 
preme Court (UKSC), touched on guardianship in public speeches, ${ }^{11}$ including one entitled: The Supreme Court: Guardian of the Constitution? ${ }^{12}$ In that speech, she begins by questioning whether the UKSC fulfils the guardian role, and ends by noting that, to a certain extent, the Court functions as "the guardians of the U.K. Constitution." 13 This latter assertion arose within the context of the first major Brexit case, Miller $v$. Secretary of State, ${ }^{14}$ in the sense that the government stopped arguing that the procedure behind the triggering of Article 50 to leave the European Union was not justiciable. The government's acceptance that the issue could be heard by the courts, at least in Lady Hale's eyes, added kindle to the prospects of the UKSC's constitutional guardian status. Ultimately, the case allowed the UKSC to play a part in determining the process of the United Kingdom's exit from the European Union.

Outside of the U.K. context, however, the tendency for judges and others to proclaim courts as constitutional guardians or guardians over various rights and freedoms is much more pronounced. ${ }^{15}$ This rise in judicial assertiveness corresponds with the rise in a number of other legal barometers documented by academics throughout the years, including the number of written constitutions, the number of statutory and constitutional bills of rights, the number of constitutional

dependence Bill: A consultation on an interim constitution for Scotland, https://www2.gov.scot/Resource/0045/00452762.pdf. See Bogdanor, supra note 5 .

11. See Lady Hale, Speech at the Public Law Project Conference: Who Guards the Guardians? 1 (Oct. 14, 2013), https://www.supremecourt.uk/ docs/speech-131014.pdf (acknowledging that "[i] t is a truth . . that judicial review is . . ' a critical check on the power of the state, providing an effective mechanism for challenging the decisions, acts or omissions of public bodies to ensure that they are lawful.'").

12. Lady Hale, Deputy President of the Supreme Court, The Supreme Court: Guardian of the Constitution? (Nov. 9, 2016), https://www .supremecourt.uk/docs/speech-161109.pdf.

13. See, Brian Christopher Jones, Dissonant Constitutionalism and Lady Hale, 29 King's L.J. 177, 182-83 (2018) (emphasis added).

14. R. v. Secretary of State for Exiting the European Union [2017] UKSC 5, (appeal taken from N. Ir.).

15. See, e.g., Kim Lane Scheppele, Guardians of the Constitution: Constitutional Court Presidents and the Struggle for the Rule of Law in Post-Soviet Europe, 154 U. PA. L. Rev. 1757, 1772 (2006). 
courts, and the wide powers that constitutional courts wield. ${ }^{16}$ It is no surprise that over the past few decades popular books include The Global Expansion of Judicial Power, ${ }^{17}$ GovERNING WITH Judges, ${ }^{18}$ and TOWARDS JuRISTOCRACY. ${ }^{19}$ This article complements these works, providing further evidence that legal mechanisms and legal actors are the favoured routes for constitutional adjudication nowadays. Indeed, a highly legalas opposed to political-form of constitutionalism is increasingly how most states structure their constitutional systems. Whether this turn is beneficial for the health of many democracies remains up for debate, and this could be important when identifying the constitutional guardians within a particular system.

\section{Rise of the Guardian Language}

The idea of state guardianship is traceable as far back as Plato's Republic. When articulating the differences between rulers and subjects, Plato maintained that rulers should be chosen from the elders within a society, and only the most respected elders could be considered "guardians." 20 Humanized through their education, ${ }^{21}$ these guardians "ought to be wise and efficient, and to have a special care of the State." 22 Although such guardians would not be intrinsically superior to others, their "knowledge of the general good and the best

16. See, e.g., Tom Ginsburg, Written Constitutions Around the World, INSights on L. \& Soc'y, Spring 2015, at 4 (charting the number of written constitutions in force over the past couple centuries and demonstrating a significant increase throughout the years).

17. The Global Expansion of Judicial Power (C. Neal Tate \& Torbjörn Vallinder eds., 1995) (one of the first texts to note and comment on the global judicialization of politics).

18. Alec Stone Sweet, Governing with Judges: Constitutional PolitICS IN EUROPE (2000) (tracking the rise of constitutional courts in Europe and their adjudicative techniques into constitutional politics).

19. Ran Hirschl, Towards Juristocracy: The Origins and ConseQuences of the New Constitutionalism (2004) (challenging the idea that rights constitutionalization and judicial review produces progressive outcomes).

20. Plato, The Republic 222 (Benjamin Jowett trans., Andrews UK Limited 2d ed. 2012).

21. Id. at $125-26$.

22. Id. at 222. This is later qualified as "those who in their whole life show the greatest eagerness to do what is for the good of their country, and the greatest repugnance to do what is against her interests." Id. at 223. 
means to achieve it" would make them "experts in governing."23 Without a doubt, Plato's ideas have long endured. Writing on the cusp of the twenty-first century, Robert Dahl notes that " $[\mathrm{t}]$ he claim that government should be turned over to experts deeply committed to rule for the general good and superior to others in the knowledge of the means to achieve it . . . has always been the major rival to democratic ideas." 24

From a constitutional perspective, there are major questions as to when the use of guardian language arose and when it subsequently took hold. Some may consider Sir Edward Coke's statement in Bonham's Case as a potential beginning, where he said that "in many cases the common law will control Acts of Parliament and adjudge them to be utterly void." 25 These were provocative words in 1610, and remain so today. Coke's statement explicitly declares that statutory law is subservient to judicial control, which is how some guardianship elements are expressed today. ${ }^{26}$ After the Glorious Revolution in 1688 and the eventual entrenchment of parliamentary sovereignty, however, the guardian discourse took a different direction within the British context. ${ }^{27}$ Blackstone, writing in the mid-eighteenth century, displays an understanding of the constitution more aligned with its post-revolution trajectory. He labels those individuals serving in Parliament as "guardians of the English constitution," adding that they are "the makers, repealers, and interpreters of the English laws; delegated to watch, to check, and to avert every dangerous innovation, to propose, to adopt, and to cherish any solid and well-weighed improvement." 28 Given the wide success of Blackstone's CoMMENTARIES, this remains a prominent statement on the role of constitutional guardians.

In the American context, Alexander Hamilton discusses the judiciary's "duty as faithful guardians of the Constitu-

23. Robert A. Dahl, On Democracy 70 (2000).

24. Id. at 69 .

25. S. E. Thorne, Dr. Bonham's Case, 54 Law Q. Rev. 543, 547 (1938).

26. See infra Part II(B).

27. R.H. Helmholz, Bonham's Case, Judicial Review, and the Law of Nature, 1 J. Legal Analysis 325, 329 (2009). That did not stop American judges and scholars from picking it up, as it is commonly cited in the American context as a justification for judicial review. $I d$. at 327 .

28. 1 William Blackstone, Commentaries *9. 
tion." ${ }^{99}$ Importantly, however, Hamilton does not single out the members of the judiciary as the sole faithful guardians of the Constitution, but rather acknowledges their guardianship capacity in the wider context of other constitutional actors, including citizens. ${ }^{30}$ Despite the prominence of the Federalist papers, neither the federal Constitution of 1789 nor any subsequent U.S. state constitutions explicitly refer to members of the judiciary as guardians. Instead, many U.S. state constitutions emphasize the consolidation of political power in the citizenry. For example, Section 2 of the Connecticut Constitution notes, "[a]ll political power is inherent in the people, and all free governments are founded on their authority, and instituted for their benefit; and they have at all times an undeniable and indefeasible right to alter their form of government in such manner as they may think expedient." ${ }^{11}$ States that joined the Union at a later date, such as New Mexico and Alaska, use similar language. ${ }^{32}$ Therefore, while prominent thinkers discussed the judiciary as constitutional guardian at the time of the nation's founding, the founding documents themselves did not reflect such an approach. Considering the above, guardianship language did not apparently take hold before or during America's founding era.

After the founding, the judiciary expanded and clarified its own role in the seminal case of Marbury $v$. Madison, a decision in which the Supreme Court established itself as having the power to "say what the law is." ${ }^{3}$ This decision furthered the Supreme Court's role as the ultimate constitutional authority and established a basis for expanding the judiciary's constitutional jurisdiction, similar to the attempt in Bonham's

29. The Federalist No. 78 (Alexander Hamilton).

30. Id. Critically, Hamilton says the judiciary was or would be faithful guardians, not the faithful guardians or the only guardians.

31. Conn. Const. art. I, $\S 2$.

32. N.M. Const. art. II, $\$ 2$ ("All political power is vested in and derived from the people: all government of right originates with the people, is founded upon their will and is instituted solely for their good."); Alaska Const. art. I, § 2 ("Source of government: All political power is inherent in the people. All government originates with the people, is founded upon their will only, and is instituted solely for the good of the people as a whole.").

33. Marbury v. Madison, 5 U.S. 137, 177 (1803). 
Case, but without explicitly mobilizing the guardian rhetoric. ${ }^{34}$ Nevertheless, against the backdrop of the growing power of the American judiciary, scholars and judges made more explicit guardianship connections. Writing in the late nineteenth century, renowned Oxford professor A.V. Dicey confronted the idea of guardianship. When describing the U.S. system of federalism and the judiciary's role, he stated that "the Bench of judges is not only the guardian but also at a given moment the master of the constitution." 35 Although the latter phrase received criticism, Dicey retained it through multiple editions. Despite Dicey's characterization of the American context, the portrayal of the judiciary as constitutional guardian was not prominent for most of the early and mid-twentieth century.

Notwithstanding reticence around the constitutional guardianship language in the common law context, other jurisdictions address the idea in depth. A great debate ensued in the 1920s and 1930s between Hans Kelsen and Carl Schmitt on the subject of constitutional guardianship. In brief, Schmitt argued that the executive is the proper constitutional guardian, while Kelsen contended that a constitutional court should be recognized as such. ${ }^{36}$ Their debate focused mostly on the German context, and the prospect of the legislature or other constitutional actors playing a guardianship role did not receive much consideration. Although the debate centered on the contemporary German context, Kelsen's argument in favor of a constitutional court was recognized widely, as evinced by the dramatic increase in the number of constitutional courts throughout the world, ${ }^{37}$ and especially in continental Europe. ${ }^{38}$ Beyond mere establishment, until today the courts' ancillary powers continue growing, as the judiciary polices a wider extent of the political process, including the dissolution

34. There is much more on the effects of Marbury below. See infra pp. $14-18$.

35. A.V. Dicey, Introduction to the Study of the Law of the ConstiTUTION 100 (8th ed. 1982).

36. The Guardian of the Constitution, supra note 3 , at 5.

37. See, e.g., Tom Ginsburg, The Global Spread of Constitutional Review, in The Oxford Handbook of Law and Politics 81, 85-88 (Keith E. Whittington et al. eds., 2008) (detailing the adoption of constitutional review in new democracies around the world during the era of decolonization and following the fall of the Berlin Wall).

38. See SweEt, supra note 18, at 34-49. 
of political parties. ${ }^{39}$ While the Kelsen-Schmitt debate is significant to the discussion here, it occurred well before the use of constitutional guardian language took hold, and therefore does not provide an answer to the question of when the use of such language rose to prominence.

Without a definitive moment when the idea and use of constitutional guardianship became commonplace, this inquiry turns to a survey of written constitutions, legal judgments from a number of common law jurisdictions, and international news reports to determine when and where this language arose.

\section{A. Written Constitutions Using Guardian Language}

Given the rise of constitutional guardian language in relation to the judiciary, it is reasonable to begin an inquiry with the most formal possible origins of such language: written constitutions. One might reasonably expect that if courts, scholars, journalists and others use this language in relation to judiciaries, then constitutions will have granted them this status. This section examines a number of written constitutions and determines whether these founding documents explicitly designate the judiciary as constitutional guardians. This inquiry considers only constitutions that are currently in force, and not past constitutions subsequently replaced.

The vast majority of written constitutions throughout the world lack any type of explicit guardian language beyond that used in a parental or legal guardian manner. ${ }^{40}$ However in constitutions that do employ protecting and defending guardian language, though not necessarily directed at the judiciary-most were implemented in the past three decades: Bhu-

39. Tom Ginsburg \& Zachary Elkins, Ancillary Powers of Constitutional Courts, 87 Tex. L. Rev. 1431, 1440-44 (2009).

40. Of course, beyond the general protecting and defending nature of guardianship, some constitutions do use the term in a more parental or legal guardian manner, especially in relation to children or incapacitated adults. This analysis does not include that language. For example, in Chapter 2 of the Jamaican Constitution, it states, "[p] rovided that a person who has not attained the age of twenty-one years (other than a woman who is or has been married) may not make an application under this subsection himself but an application may be made on his behalf by his parent or guardian." JAMAICAN Const., July 25, 1962, No. 1550, ch. II. This type of guardian language is not included in this study. 
tan (2008); Burkina Faso (1991); Burundi (2005); Chad (1996); Djibouti (1992); Gabon (1991); Hungary (2011); Mali (1992); Mauritania (1991); Paraguay (1992); Rwanda (2003); Senegal (2001); Sierra Leone (1991); Somalia (2012); Swaziland (2005); and Togo (1992). ${ }^{41}$ Only three constitutions that use explicit constitutional guardian language predate 1990: France (1958), Uruguay (1967), and Micronesia (1978). In terms of explicit guardian language, Figure 1 shows that this language and the approach it establishes primarily took hold around the 1990s, and has continued, albeit to a limited extent, in the years since. Looking only at the current and ongoing decade, the number of written constitutions using explicit guardian language equals the total that came into force from 1950-1989. Thus, although use spiked in the 1990s, guardianship language still occurs much more frequently in contemporary constitutions than it did in previous eras.

Figure 1. Constitutions Using Guardian Language: 1950-PRESENT*

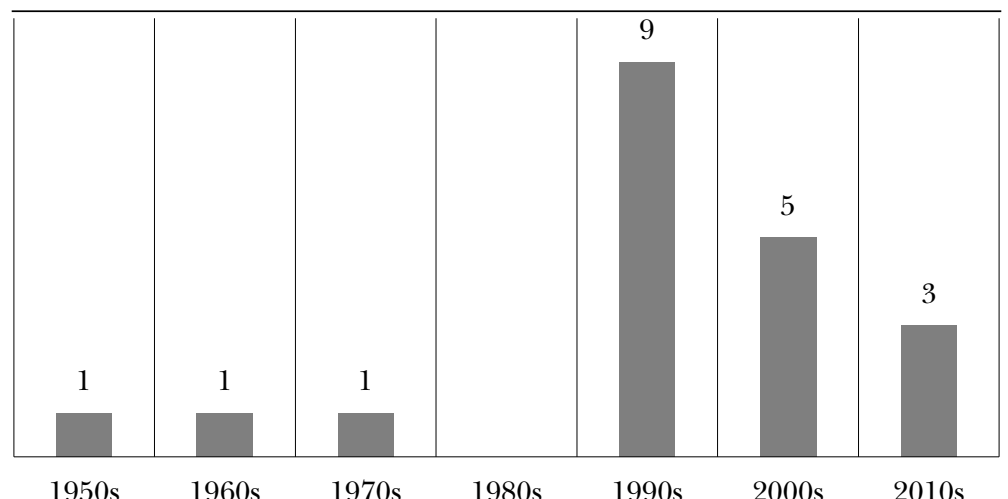

* Based on a search for "guardian" language on the Constitute Project website. ${ }^{42}$

41. Constitute: The World's Constitutions to Read, Search, \& ComPARE, https://www.constituteproject.org/ (last visited Mar. 3, 2019) (amalgamating data on constitutions from around the world). Not all of these instances necessarily identify the judiciary as the guardian of the constitution, but they all do use "guardian" language in relation to one or more branches. The specifics of such language, such as who they identify as guardian, are discussed further below. Also, some of the constitutions on the Constitute Project website are translations, and that needs to be taken into consideration as well.

42. Id. (follow "Explore Constitutions" hyperlink and then search 
Importantly, constitutions vary in the phrasing which establishes the extent of judicial power. The most common phrasing provides that the power to interpret the constitution is vested in the judiciary or in a particular set of courts. Such phrasing does not explicitly use the term guardian. Some constitutions, like those in force in Germany and Taiwan, which embolden the judiciary with wide-ranging powers, use this more typical phrasing. Germany's Basic Law states, " $\mathrm{t}]$ he judicial power shall be vested in the judges; it shall be exercised by the Federal Constitutional Court, by the federal courts provided for in this Basic Law, and by the courts of the Länder." 43 Taiwan's Constitution reads: "[ $\mathrm{t}]$ he Judicial Yuan shall interpret the Constitution and shall have the power to unify the interpretation of laws and ordinances." ${ }^{4}$ Both thereby express the more traditional conceptions of judicial power that is widespread in older constitutions. They enshrine members of the judiciary as faithful interpreters of a constitution or holders of judicial power, rather than judges as constitution makers or guardians of the document.

Newer constitutions, in contrast, are more factional. They allot wider and more explicit powers to constitutional courts in lieu of other branches, though many do so without using guardianship language. The South African Constitution, for example, states that the Constitutional Court "makes the final decision whether a matter is within its jurisdiction" 45 and also "makes the final decision whether an Act of Parliament . . . is constitutional." 46 The Constitution thereby specifically and explicitly allocates broad powers to assess compliance with the Constitution to the Constitutional Court. ${ }^{47}$ Even then, however, it does not explicitly refer to the Court as $a$ guardian, or even the guardian of constitutional values. Other constitutions use different language to hint at or imply such guardianship. For example, the Czech Republic Constitution reads: "[t]he Constitutional Court is the judicial body responsible for the

"guardian" in the search bar).

43. Grundgesetz [GG] [BAsic LAw], art. 92, translation at https:// www.btg-bestellservice.de/pdf/80201000.pdf.

44. Minguo Xianfa art. 78 (1947) (Taiwan).

45. S. Afr. Const., $1996 \S 167$ (3) (c).

46. Id. $\S 167(5)$.

47. Id. $\$ 167(4)$. 
protection of constitutionality." 48 These examples demonstrate that some constitutions go beyond the faithful interpreter language, either explicitly expanding the powers of constitutional courts or implying some type of enhanced protector role. The Czech and South African Constitutions are significant because they were written in the midst of the 1990s, when constitutional guardian language increased dramatically. ${ }^{49}$

Not all constitutional guardian language, however, refers to the judiciary. Several of the constitutions included in Figure 1 explicitly identify guardians outside of the judicial context. Senegal's 2001 Constitution explicitly states, "[t]he President of the Republic is the guardian of the Constitution," 50 and Hungary's asserts that the President, "shall embody the nation's unity and shall safeguard the democratic operation of state organisation." ${ }^{1}$ Other constitutions that explicitly identify the president as "guardian of the constitution" include the constitutions of Mali, ${ }^{52}$ Mauritania, ${ }^{53}$ Sierra Leone, ${ }^{54}$ and Somalia. ${ }^{55}$ Such labelling may indicate power struggles in action, which could be a feature of increasingly factional constitutional language. ${ }^{56}$ Given that executive branches are often the ones that attempt constitutional reform, it is unsurprising that some of the newer constitutions anoint them as guardians. For example, in Hungary the Fidesz Party enacted a new constitution after their sweeping election victory in 2010, and deemed the president "guardian of the democratic functioning of state operation." ${ }^{57}$ Of course, nominating just one per-

48. Ústavní zákon c. 1/1993 Sb., Ústava Ceské Republiky [Constitution of the Czech Republic].

49. The Czech Constitution came into force in 1993, and the South African Constitution came into effect in 1996. Id.; S. Afr. Const., 1996.

50. Constitution of the Republic of Senegal, art. 42. It then later notes, "[t]he judicial power is the guardian of the rights and freedoms defined by the Constitution and the law." Id. art. 91.

51. Magyarország Alaptörvénye [The Fundamental law of Hungary], Alaptörvény, art. 9(1) (Hung.).

52. Constitution of the Republic of Mali 1992, art. 29.

53. Constitution of Mauritania 1991, art. 24.

54. Constitution of Sierra Leone 1991, art. 40(3).

55. Provisional Constitution of the Federal Republic of Somalia Aug. 1, 2012, art. 87(1)(c).

56. See infra Part III(A).

57. Hungarian Const. art. 9(1). 
son, such as a president, is just as problematic-or perhaps worse-than nominating one branch to do the guarding, as it diminishes the collective status of constitutional guardianship. To put such weighty endeavours on one actor is also inherently risky, as dictatorial or tyrannical leaders may abuse such powers.

The guardianship role can also be over particular rights or liberties, rather than the constitution as a whole. Some of the constitutions that nominate the president as a more general guardian also appoint the judiciary as guardian of particular rights or liberties. This latter qualification of guardianship is the most common type of classification for the judiciary under written constitutions. For example, the French Constitution notes that the judiciary is "guardian of the freedom of the individual"; 58 the Rwandan Constitution states that "[t] he Judiciary is the guardian of human rights and freedoms";59 and Chad's Constitution asserts that the judiciary "is the guardian of the freedoms and of individual property and sees to the respect of the fundamental rights." 60

Swaziland is perhaps the most inclusive and forthcoming in terms of its constitutional guardian language, noting in its preamble, " $[\mathrm{w}]$ hereas all the branches of government are the Guardians of the Constitution, it is necessary that the Courts be the ultimate Interpreters of the Constitution." 61 This language focuses on guardianship as a collective endeavour, but gives ultimate interpretive power to the judiciary. On the basis of this collective approach to guardianship, the Swaziland Constitution is unique for two major reasons. First, it acknowledges that all branches are constitutional guardians, something that no other written constitution explicitly does. Second, it directly establishes, in the preamble, that the courts will be the ultimate interpreters. This contrasts with other jurisdictions where supreme or constitutional courts wield immense power, despite their articulated powers in the constitution having a significantly less prominent place. ${ }^{62}$

58. 1958 Const. art. 66 (Fr.).

59. Constitution of the Republic of Rwanda 2003, art. 43.

60. Constitution of the Republic of Chad 1996, art. 143.

61. Constitution of the Kingdom of Swaziland 2005, pmbl.

62. See the U.S. Constitution, which does not mention judicial power until art III(1), which is over halfway through the document. 
Only two constitutions explicitly label the judiciary as the sole constitutional guardian, rather than qualifying guardianship to particular rights, liberties, or freedoms, or disaggregating this role among the branches. Paraguay's Constitution asserts that " $[\mathrm{t}]$ he Judicial Power is the guardian of the Constitution. It interprets it, it complies with it and it has it complied with." 63 Similarly, Bhutan's Constitution notes, "[t]he Supreme Court shall be the guardian of this Constitution and the final authority on its interpretation." 64 Despite the similar exclusive guardianship role for the judiciary, the constitutions differ in that the Paraguay Constitution establishes an extremely wide role for the judiciary, noting the interpretative and compliance functions explicitly. In contrast, the Bhutan Constitution emphasizes the traditional interpretative role more commonly ascribed to the judiciary. While other constitutional language may strongly imply constitutional guardianship for the judiciary, only these two written constitutions formally and explicitly establish this approach.

In most constitutions, judicial power is seldom explicitly mentioned. The German Basic Law, for example, does not articulate the power of the judiciary until Article $92,{ }^{65}$ and the Japanese Constitution does not do so until Article 76. ${ }^{66}$ These examples are quite typical in terms of where judicial power is often situated in constitutions. Even the Paraguay and Bhutan Constitutions, which anoint the judiciary as the sole guardians of their Constitutions, do not do so until Article $247^{67}$ and Article $111,{ }^{68}$ respectively. Leaving this language to the middle or end of a constitution, rather than acknowledging constitutional guardians up front, is a major defect of many written constitutions.

Indeed, it appears that many constitutions articulate vastly important matters, such as ultimate constitutional guardianship, in places that are difficult for citizens to locate. ${ }^{69}$ One reason for doing so may be that if constitutions acknowledged the extent of judicial powers up front, they would face de-

63. Constitution of Paraguay 1992, art. 247.

64. Constitution of the Kingdom of Bhutan, art. 111.

65. Grundgesetz [GG] [Basic Law], art. 92.

66. Nihonkoku Kenpo [Kenpo] [Constitution], art. 76 (Japan).

67. Constitution of Paraguay, art. 247.

68. Constitution of the Kingdom of Bhutan, art. 111.

69. Assuming, of course, that citizens read and consult constitutions. 
creased likelihood of enactment. After all, the language of preambles and much initial constitutional text largely revolves around citizen power. If contemporary drafters removed language relating to the citizenry, or heavily qualified such language with vast judicial powers, then this may provide some voters hesitation over the proposed text. Leaving the labelling of constitutional guardians or the articulation of very strong judicial powers to relatively inconspicuous sections of a constitution is deeply problematic. Such items should feature prominently in the constitutional text, so citizens are fully informed of what they are voting on.

The discrepancy between the language in the Swaziland constitution and that found in many U.S. state constitutions provides an interesting contrast regarding the placement and reference to significant constitutional authority. As noted above, an extremely common initial provision in U.S. state constitutions is to note that all political power originates in "the people." 70 Given that many U.S. state constitutions were written in the nineteenth and twentieth century, more contemporary constitutions-such as those of Bhutan, Paraguay, and Swaziland-may acknowledge judicial power in a more robust and explicit manner. Such acknowledgements may be a sign of increasing acceptance for the enhanced role of the judiciary worldwide. Nevertheless, even if one disagrees with strong judicial powers within a constitutional state, at least the Swaziland preamble candidly acknowledges that the judiciary plays a major role in constitutional maintenance. ${ }^{71}$ The same cannot be said for many other constitutions.

\section{B. Legal Judgments Using Guardian Language}

Constitutional guardianship language arises also in legal judgments. ${ }^{72}$ The survey performed for this article included three common-law jurisdictions-the United States, Canada,

70. See supra notes $31-32$.

71. Constitution of the Kingdom of Swaziland, pmbl.

72. While the prior section of the article filtered out references to "legal guardian" as opposed to a "constitutional guardian", the inquiry here required a different approach. To ensure consistency across jurisdictions, the following searches only include the phrase "guardian/s of the constitution." Given the wide amount of legal judgments that discuss "legal guardianship" in relation to children or incapacitated adults, searching for this phrase helped narrow the statistical inquiry. 
and Australia-and identified that although some of the explicit use of guardian language predates the complementary appearances in some contemporary constitutions, most of its use occurred over recent decades. One of the main articulations of the courts as a constitutional guardian came in the 1971 U.S. Supreme Court case of Perez v. Ledesma, where in a five-to-four judgment the Court found that it had no jurisdiction to review a district judge's decision invalidating a local ordinance. ${ }^{73}$ A concurring opinion by Justice Brennan notes that the federal courts are "the primary guardians of constitutional rights," and that federalism concerns should not be a controlling factor. ${ }^{74}$ Compared to some other jurisdictions analysed below, the U.S. federal judiciary has not been overly assertive in terms of its guardian status, and such wording appears rarely, especially coming from the U.S. Supreme Court.

The same does not necessarily hold true in U.S. state courts, which have increasingly employed the terminology within the past few decades. ${ }^{75}$ This is surprising, given that no U.S. state constitution explicitly labels the judiciary as constitutional guardians. Figure 2 tracks the use of guardian language in state court judgments. In state courts, constitutional guardian language did not start gaining traction until the 1950s, and did not begin to peak until the 1970s, when it almost doubled from the previous decade. While that is potentially attributable to the Perez v. Ledesma concurrence noted above, it seems unlikely that increasing state court use of the term can be understood on the basis of the concurrence alone.

73. Perez v. Ledesma, 401 U.S. 82, 86 (1971).

74. Id. at 118 (Brennan, J., concurring). This passage was later cited in Steffel v. Thompson, 415 U.S. 452, 463 (1974).

75. The numbers presented in Figure 2 represent only a small fraction of the vast number of cases heard before state courts each decade. Nevertheless, the data reinforces the trend seen in other areas regarding the use of constitutional guardian language. 
Figure 2. Guardian Language in U.S. State Court JudGeMENTS: 1900-PRESENT*

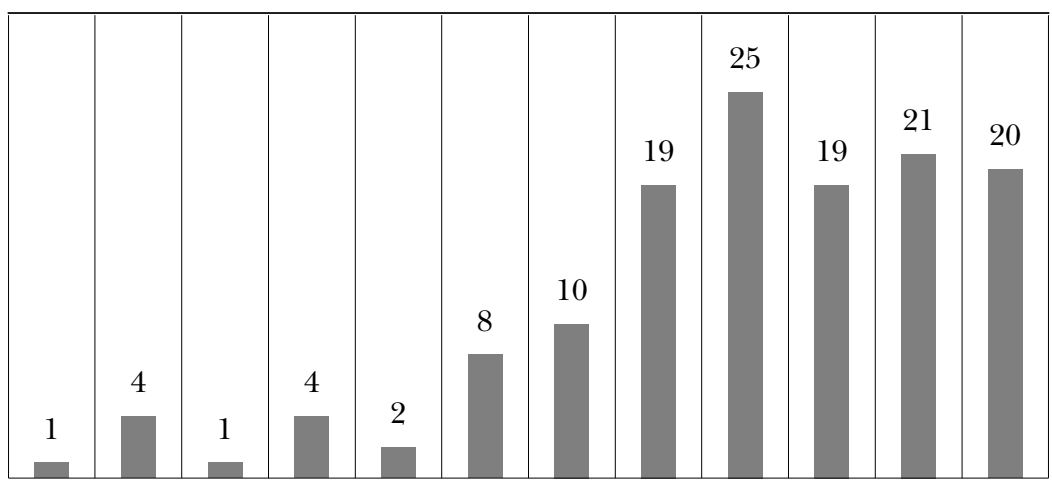

1900s 1910s 1920s 1930s 1940s 1950s 1960s 1970s 1980s 1990s 2000s 2010s

*Based on a Westlaw search of the phrase "guardian of the constitution" in U.S. state court judgements $(n=147)$.

Given that virtually all U.S. state constitutions were written before the rise in constitutional guardian language, it is unsurprising that judiciaries or state supreme courts are not labelled in that specific manner. Nevertheless, the trend in usage from the 1970s onwards appears consistent.

Similarly, the federal Canadian courts have been relatively active over the past few decades in employing such language. In the case of Hunter $v$. Southam Inc [1984], undertaken shortly after the implementation of the Canadian Charter of Rights (1982), ${ }^{76}$ the leading judgment notes, " $[\mathrm{t}]$ he judiciary is the guardian of the constitution and must, in interpreting its provisions, bear these considerations in mind."77 As Figure 3 demonstrates, use of similar guardianship language has slowly increased since then.

76. Constitution Act 1982, Part I. Enacted as Schedule B to the Canada Act 1982 c. 11.

77. Hunter v. Southam Inc., [1984] 2 S.C.R. 145. 
Figure 3. Guardian Language in Canadian Federal Court JudGMENTS: 1980-PRESENT*

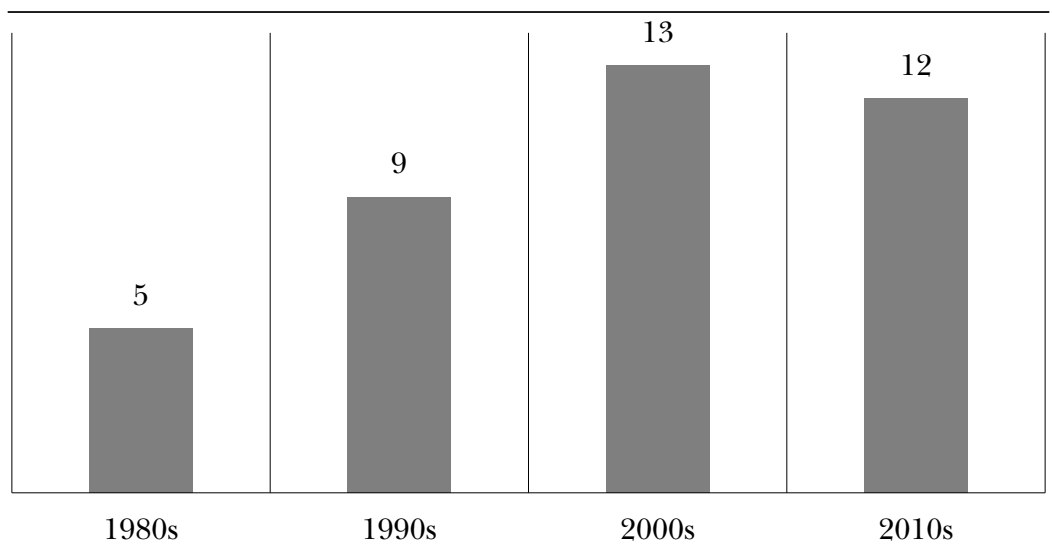

*Based on a Westlaw search of the phrase "guardian of the constitution" in Canadian federal court judgements $(n=39)$.

In Australia guardianship elements were first introduced in the Australian Communist Party Case (1951), as the High Court employed Marbury v. Madison ${ }^{78}$ to assert that the doctrine of courts deciding whether a statute is within its constitutional powers was "axiomatic" within the Australian system. ${ }^{79}$ Despite the significance of Australian Communist Party, explicit use of phrase "guardian of the constitution" was only used three times by the High Court from 1960-1999. ${ }^{80}$ Yet in the 2000s, it was used in five High Court judgments, ${ }^{81}$ almost doubling its use throughout the previous four decades combined. The reason behind such a dramatic increase is unclear. Unlike the Canadian experience, where the term gained traction slowly, Australia's 2000s spike appears to have come out of

78. Marbury, supra note 33.

79. Australian Communist Party v Commonwealth (1951) 83 CLR 1 at 262-63.

80. W. Austl. v Hamersley Iron Pty Ltd. [No. 2] (1969) 120 CLR 74, 79; Victoria v Commonwealth (1975) 134 CLR 81, 118-19. Kruger v Commonwealth [1997] 190 CLR 1, 175 (Gummow J) (Austl.).

81. The five judgments are: Chief Exec Officer of Customs $v$ El Hajje [2005] 224 HCA 35, 124; Forge v Australian Sec E् Investments Comm'n (2006) 228 CLR 45, para 125 (Kirby, J); NSW v Commonwealth (2006) 229 CLR 1, 210, 231; Thomas v Mowbray (2007) 233 CLR 307, para 229 (Kirby, J); MZXOT v Minister for Immigration $\mathcal{E}^{\circ}$ Citizenship [2008] HCA 28, 42. 
nowhere. Despite this temporary increase, however, such language has not been used once by the High Court in the current decade.

\section{Law Journal and News Articles Using Guardian Language}

Finally, this inquiry examines the use of guardian language in law journal scholarship and news articles. For the law journal section, this article consulted Hein Online's Law Journal Library to search for the phrase "guardian of the constitution." The results produced 1,142 results in total, from law journals around the world. ${ }^{82}$ Of course, it is important to consider the dramatic growth in the number of legal periodicals throughout the twentieth century, which likely accounts for some of the increase in the use of the language across decades. Regardless, the data evinces substantial growth and acceptance of the phrase in the last few decades.

Figure 4. Law Journal Use of Guardian Language: 1900-PRESENT*

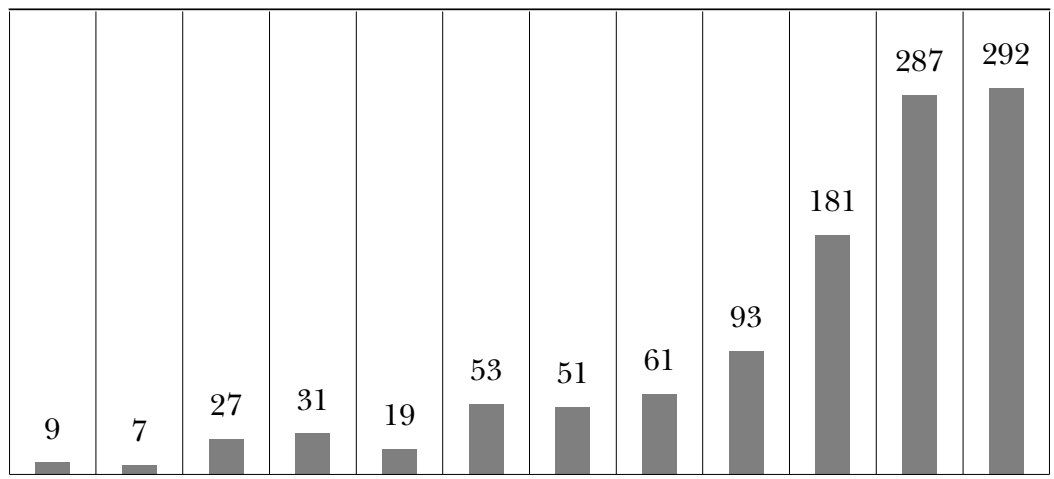

1900s 1910s 1920s 1930s 1940s 1950s 1960s 1970s 1980s 1990s 2000s 2010s

*Based on a Hein Online Law Journal Library search for the phrase "guardian of the constitution" $(\mathrm{n}=1,142)$.

Figure 4 shows an initial steep increase in the use of the phrase "guardian of the constitution" in the 1990s, continuing into in the 2000s. The use of the phrase almost doubled from the 1980 s to the 1990 s. With over eighteen months remaining,

82. The initial search was performed on May 24, 2018, and an updated search was performed on March 13, 2019. 
use in the current decade has already eclipsed the previous decade's total. This demonstrates that it is not merely official government documents augmenting the use of such language. Constitutions and legal judgments show increasing use of guardian-esque language, and the language of legal academics follows suit and expands substantially on the use of the term. Importantly, it is difficult to know whether one is driving the other, or if both are mutually reinforcing and together contributing to the growth in the use of the concept.

Beyond legal academia, news articles also manifest the growing trend. This article scoured international news articles for their use of guardian-esque language, using Westlaw's News feature. This database includes news from all available areas: Africa, Asia, Australia and New Zealand, Canada, Europe, Latin America, the Middle East, the United States, and the United Kingdom. While the database maintains an archive dating back to only 1980, there were 2,113 results in that timeframe. ${ }^{83}$ The data, as shown in Figure 5, displays a dramatic increase of language use during this time period.

Figure 5. International News Use of Guardian Language: 1900-PRESENT*

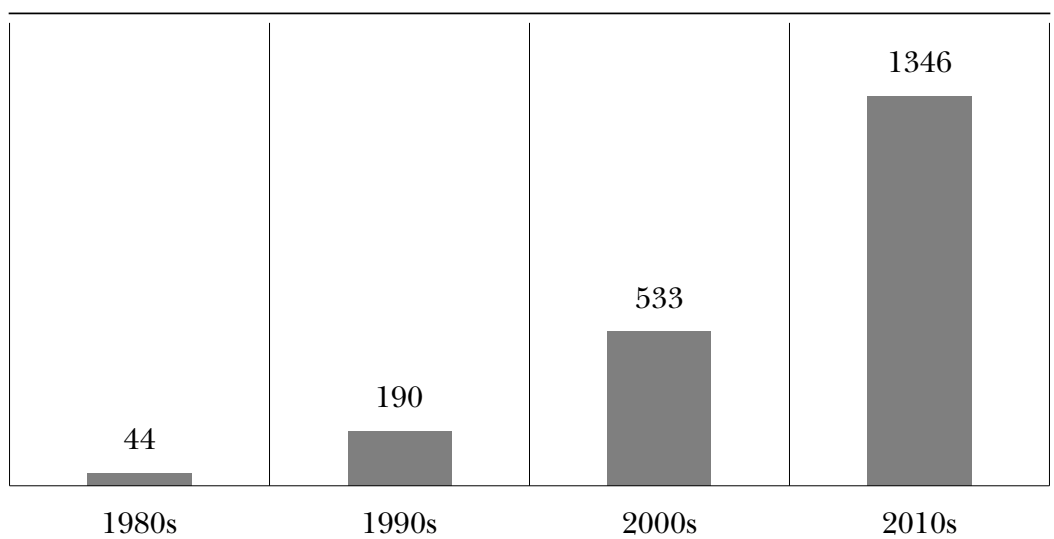

*Based on a Westlaw search of the phrase "guardian of the constitution" in the International News feature $(n=2,113)$.

83. The initial search was performed on June 22, 2018, and an updated search was performed on March 13, 2019. 
The use of the phrase "guardian of the constitution" more than doubled from the 1990s to the 2000s, and has already doubled again in the current decade. Importantly, given the low numbers in the 1980s and 1990s-when the language was being used more frequently in constitutions, legal decisions, and legal academia-it did not appear as often in the news. Accordingly, it seems the news media is not responsible for leading the growth around the phrase. Instead, they are apparently following the trend originating in other sources, such as constitutions, legal judgments, or legal scholarship.

While constitutional guardian language arose in many contexts at varying times, it is challenging if not impossible to identify the initial use of the language. From a written-constitution era perspective, there are indications that it was present before and around the American founding through the Federalist Papers and even in some state court judgments. ${ }^{84}$ Decisions such as Bonham's Case and Marbury were, and continue to be, a strong force in support of the guardianship approach and suggest the historical roots of the term. However after examining current constitutions, surveying legal judgments from several jurisdictions, and searching law journal and media use of the language, the majority of evidence suggests that the more widespread use of such language came to the fore over the last three-to-four decades. These trends also suggest that official documents, such as constitutions and legal judgments, may drive the use of such language, while the media reacts and follows.

\section{The Significance of the Constitutional GuARdian LANGUAGE}

This article argues that there are two main reasons this linguistic shift matters. First, it is unnecessarily factional and may foment inter-branch tension. While constitutional power

84. For examples of early state court judgements, see Riley v. Riley, 3 Day 74, 81 (Conn. 1808) ("It is a sufficient answer to this objection, that the supreme court of the United States, the peculiar guardian of the constitution, did not think such a decision as at all impugning that clause of the constitution."); Commonwealth v. Lewis, 6 Binn. 266, 283 (Pa. 1814) ("But the judiciary are the guardians of the constitution, and it is a presumption in favour of the law that they have not questioned it."). See also supra note 28 and accompanying text. 
struggles are not new, ${ }^{85}$ guardianship language often originates from a judicial branch which the constitution identifies as faithful interpreters of the law or Constitution, rather than its ultimate guardians. This is especially true in commonlaw jurisdictions where supreme or apex courts are not explicitly provided the same extensive powers as modern constitutional courts. The interpreter and guardian roles are importantly different. Interpretation is a crucial but undoubtedly narrower role for the judiciary, while guardianship implies a broader power to actively protect and defend the constitution. This is amplified further when courts refer to themselves as the ultimate constitutional guardians within their respective jurisdictions. ${ }^{86}$ Using this language, courts often attempt to exclude or dissuade other constitutional actors, thus displaying an unnecessarily factional attitude towards the respective constitution. ${ }^{87}$

Second, such language is exceedingly and unnecessarily paternalistic. The manner in which the courts use guardianship language follows a more legalized conception of the role, rather than adhering to a general responsibility to protect and defend. Such language may also lull citizens into believing they have no responsibility in ensuring the maintenance of constitutional principles. Given these combined effects, this paper argues that guardian language usurps an individual and collective responsibility for protecting constitutional values and norms and makes citizens overly reliant on one person or branch of government to act as guardian.

\section{A. The Judiciary's Use of Unnecessarily Factional Language}

In asserting their authority over the other branches, the courts often employ unnecessarily factional language, attacking the legitimacy or will of other constitutional actors. The renowned U.S. case of Marbury $v$. Madison ${ }^{88}$ had a far broader impact beyond establishing for the judiciary the ability to

85. See Hanna Fenichel Pitkin, The Idea of a Constitution, 37 J. Legal Educ. 167, 168 (1987) (“[Constitutions] are human creations, products of convention, choice, the specific history of particular people, and (almost always) a political struggle in which some win and others lose.").

86. See the Canadian case of Hunter v. Southam above, supra note 77.

87. See, infra, Part III(A) below.

88. Marbury v. Madison, 5 U.S. 137 (1803). 
strike down legislation. Linguistically, it outlined a roadmap for judges-in the United States and in other jurisdictionsfor expanding judicial power. Through its bold assertion that it is "emphatically" the judiciary's job to say what the law is, ${ }^{89}$ and its repeated reference to and idolisation of a written constitutional document, the judgment now serves as a well-worn and time-honoured justification for judicially-mandated constitutional intervention. Indeed, the decision laid a basic foundation for factional constitutional language designed to increase judicial power in the face of other claims by worthy constitutional actors.

Academics and practitioners today widely recognize that Chief Justice Marshall relies "on more indirect arguments" to support the holding. ${ }^{90}$ Much of the decision revolves around rhetoric, as opposed to any legal precedent or constitutional provision, as a basis for judicial review or the striking down of legislation. Marshall also emphasizes the written nature of the U.S. constitution, ${ }^{91}$ in contrast to the U.K. constitutional structure, as a basis for increased judicial authority. His decision justifying a judicial strike-down power by extolling the virtues of the American Constitution is one of the most influential and widely cited judicial decisions in history, and serves to establish a strong but implicit guardianship role for the judiciary. ${ }^{92}$ There remains little doubt that the legendary decision continues to inspire judges to be more proactive in asserting judicial authority. ${ }^{93}$

The Israeli case of Bank Mizrahi provides an incredible contemporary example of the use of factional language. In that case, the Supreme Court decided its Basic Law contained "supra-legal" constitutional status, abruptly transforming the

89. Id. at 177 .

90. Adam Tucker, Constitutional Writing and Constitutional Rights, Pub. L., Apr. 2013, at 345, 352; Brian Christopher Jones, Preliminary Warnings on “Constitutional" Idolatry, Pub. L., Jan. 2016, at 74, 84.

91. Marbury, 5 U.S. at 176, 178.

92. See, e.g., Mark Tushnet, Marbury v. Madison Around the World, 71 Tenn. L. REv. 251, 260 (2004) (arguing that "Marbury is the likely origin of strongform review," and that this system of review has been widely copied throughout the world).

93. See, e.g., Stefanus Hendrianto, Law and Politics of Constitutional Courts: Indonesia And the Search for Judicial Heroes (2018) (citing Marbury throughout as an inspiration for the Indonesian Constitutional Court). 
country from "a state based on the English model of parliamentary sovereignty" into a "constitutional state," 94 and thereby considerably expanding the scope of judicial review. ${ }^{95}$ Mirroring Marbury, the president of the Supreme Court at the time, Justice A. Barak, praised the enactment of the Basic Law: Human Dignity and Liberty, ${ }^{96}$ despite the fact that it, like the U.S. Constitution, does not explicitly provide for judicial review. Barak's extraordinarily forceful and idealistic rhetoric goes well beyond that used by Chief Justice Marshall, as he declares that, "there is now the possibility that the constitutional change will be internalized; that human rights will become the 'daily bread' of every girl and boy." 97 He continues:

The prospect is of recognition of the Court's role as guardian of the constitution, balancing the constitutional values established in the constitution and supervising the constitutionality of administrative activity. The prospect is of the ascent of the glory of human rights, and enhanced goodwill and fellowship among human beings, each born in the image of the Creator. 98

Barak devotes two pages in his judgment to discussion of Marbury, dramatically noting that the "doctrine is a cornerstone of the American constitutional system. Remove it and the entire structure collapses." 99 The non-mention of judicial legislative review in the American Constitution suggests, however, that Barak's assessment is an overstatement based only on hypothetical. Nonetheless, Barak's analysis evinces the seriousness with which he understands constitutional system reliance on judicial review. Importantly, Justice Barak does not

94. Suzie Navot, Israel, in How Constitutions Change: A Comparative Study 191, 194, 198 (Dawn Oliver \& Carlo Fusaro eds., 2011); CA 6821/93 United Mizrahi Bank Ltd. v. Midgal Cooperative Village 49(4) PD 221, para. 109 (1995) (Isr.).

95. See Yoram Rabin \& Arnon Gutfeld, Marbury v. Madison and Its Impact on Israeli Constitutional Law, 15 U. MiAmi InT'L \& Comp. L. Rev. 303, 318-30 (2007).

96. Basic Law: Human Dignity and Liberty (1992). An English language version is provided by the Knesset here: https://www.knesset.gov.il/laws/ special/eng/basic3_eng.htm.

97. CA 6821/93 United Mizrahi Bank Ltd. v. Midgal Cooperative Village 49(4) PD 221, para. 109 (1995) (Isr.).

98. Id.

99. Id. para. 75 . 
just focus on American judicial review, but rather notes that judicial review for constitutional adherence exists throughout the world, and that the "twentieth century is the century of judicial review." ${ }^{100}$ He continues, "judicial review of the constitutionality of the law is the soul of the constitution itself. Strip the constitution of judicial review and you have removed its very life. The primacy of the constitution therefore requires judicial review."101 Discussing the separation of powers principle, Barak insists, "[a]djudication according to the constitution, rather than according to the law, can incidentally lead to the invalidation of a law. This invalidation is not a violation of the separation of powers, but rather its realization." 102 Reflecting on the role of judicial review and democracy, he proclaims, "[t] he substantive answer is that the judicial review of constitutionality is the very essence of democracy", and "whoever argues that judicial review is undemocratic is in effect arguing that the constitution itself is undemocratic."103 Ultimately, he believes that members of the judiciary, through judicial review itself, express the "values of the constitution" by articulating "the fundamental conceptions of society as it moves through the shifting sands of history." 104 It is difficult to find another legal judgment that so willingly transposes the essence of Marbury's factionalism without any critical examination of judicial review itself.

Additionally, even with the establishment of judicial review in Marbury, a number of prominent judges and academics are critical of these powers. Writers such as James Bradley Thayer, ${ }^{105}$ Alexander Bickel, ${ }^{106}$ Larry Kramer, ${ }^{107}$ and Jeremy

100. Id. para. 80 .

101. Id. para. 78 .

102. Id. para. 79 .

103. Id. para. 80

104. Id. para. 81 .

105. See James B. Thayer, The Origin and Scope of the American Doctrine of Constitutional Law, 7 Harv. L. Rev. 129, 130 (1893) (Thayer says in no uncertain terms regarding judicial review, "So far as the grounds for this remarkable power are found in the mere fact of a constitution being in writing, or in judges being sworn to support it, they are quite inadequate. Neither the written form nor the oath of the judges necessarily involves the right of reversing, displacing, or disregarding any action of the legislature or the executive which these departments are constitutionally authorized to take, or the determination of those departments that they are so authorized."). 
Waldron, ${ }^{108}$ among others, produced works that challenge the values explicated in Marbury and the wide expansion of judicial review more generally. Prominent constitutional scholar Mark Tushnet undertook the thought experiment of doing away with judicial review, and concluded that " $[\mathrm{t}]$ he effects of doing away with judicial review . . . would probably be rather small, taking all issues into account."109

Nevertheless, prominent examples of guardianship language exist in other jurisdictions. In Australia, the High Court noted the following in a 2006 judgment:

It is that potential that demands from this Court, which is the guardian of the Constitution, a response protective of the text and structure of the document. If this Court does not fulfil its protective role under the Constitution, what other governmental institution will do so? What other institution has the power and the will to do so? ${ }^{110}$

In Cormack $v$ Cope, the High Court emphasized the written nature of the Australian Constitution in contrast to the U.K. constitutional structure, ${ }^{111}$ emphasizing that, "the Parliament in Australia is controlled by a written Constitution." 112 The Court continued, "[w] hilst it may be true the Court will not interfere in what I would call the intra-mural deliberative activ-

106. See Alexander M. Bickel, The Least Dangerous Branch: The Supreme Court at the Bar of Politics 21 (2d ed. 1986) (Bickel stresses that, "Besides being a counter-majoritarian check on the legislature and the executive, judicial review may, in larger sense, have a tendency over time seriously to weaken the democratic process.").

107. See Larry D. Kramer, The People Themselves: Popular Constitutionalism and Judicial Review, 249-53 (2004) (noting that the original conception of American constitutionalism gave "[f]inal interpretive authority ... [ to] 'the people themselves,' ... and courts no less than elected representatives were subordinate to [the people's] judgments.”).

108. See Jeremy Waldron, Political Political Theory: Essays on InstituTIONs 195-245, 244 (2016) (Waldron specifically focuses on rights-based review, and argues that ordinary legislative procedures are preferable, as a "final review by courts adds little to the process except a rather insulting form of disenfranchisement and a legalistic obfuscation of the moral issues at stake in our disagreements about rights.").

109. Tushnet, supra note 4 , at 154.

110. NSW v Commonwealth (2006) 229 CLR 1, 210.

111. Cormack v Cope Qld (1974) 131 CLR 432, 453.

112. Id. 
ities of the Parliament, it has both a right and a duty to interfere if the constitutionally required process of law-making is not properly carried out." 113 In Bribery Commissioner v Ranasinghe, the Court recognized its "duty to see that the Constitution is not infringed and to preserve it inviolate." 114 Much of this language echoes Marbury, which consistently praises and centralizes the written nature of the Constitution while emphasizing the role of the courts within the broader system over reliance on a specific constitutional provision as justification for intervention. ${ }^{115}$

Canadian jurisprudence contains similar factional language, especially after the passage of the Charter of Rights and Freedoms in 1982. ${ }^{116}$ When first striking down a major law under the Charter, Judge Dickson stresses that "[t] he Constitution of Canada, which includes the Canadian Charter of Rights and Freedoms, is the supreme law of Canada. Any law inconsistent with the provisions of the Constitution is, to the extent of the inconsistency, of no force or effect."117 Dickson further notes, "[t] he judiciary is the guardian of the constitution and must, in interpreting its provisions, bear these considerations in mind." 118 His use of "the" renders the judiciary the exclusive guardian of the Constitution.

In a more recent case, Manitoba Métis Federation Inc. v. Canada (Attorney General) (2013), the Court repeatedly stresses their guardianship role. The decision asserts, "this Court has found that limitations of actions statutes cannot prevent the courts, as guardians of the Constitution, from issuing declarations on the constitutionality of legislation. By extension, limitations acts cannot prevent the courts from issuing a declaration on the constitutionality of the Crown's conduct."119 This establishes a broad guardianship role for the courts. Perhaps the most revealing line is this: " $[\mathrm{t}]$ he courts are the guardians of the Constitution and ... cannot be barred by mere statutes

113. Id. at 454 .

114. Bribery Commissioner v Ranasinghe [1965] AC 172, 194 (quoted in Cormack, 131 CLR at 453).

115. Marbury v. Madison, 5 U.S. 137, 176, 178 (1803).

116. Canadian Charter of Rights and Freedoms, Part I of the Constitution Act, 1982, being Schedule B to the Canada Act, 1982, c 11 (U.K.).

117. Hunter v. Southam Inc., [1984] 2 S.C.R. 145, 148.

118. Id. at 155 (emphasis added).

119. Manitoba Métis Federation Inc. v. Canada, [2013] 1 S.C.R. 623, 683. 
from issuing a declaration on a fundamental constitutional matter. The principles of legality, constitutionality and the rule of law demand no less." 120 Thus the court not only asserts that they are the proper guardians, but also proclaims that three extremely important constitutional values-legality, constitutionality, and rule of law-support such an exclusive role for the courts. The judgment ends by noting,

It is difficult to see how a court, in its role as guardian of the Constitution, could apply an equitable doctrine to defeat a claim for a declaration that a provision of the Constitution has not been fulfilled as required by the honour of the Crown. ... The Constitution is the supreme law of our country, and it demands that courts be empowered to protect its substance and uphold its promises. ${ }^{121}$

Again, there are deep echoes of the Marbury logic throughout this judgment. More significantly, the language displays a strong sense of factionalism and accordingly minimizes the role of other branches, and, by implication, the role of citizens.

\section{B. The Judiciary's Overly Paternalistic Understanding of Guardianship}

In addition to increasing factionalism, guardianship language undercuts the role of the people at the heart of the democratic constitutional state and is connected to a more consequentialist argument. This argument asserts that use of guardianship language undercuts any type of we the people or collective importance that may be present within or run through the constitution. After all, collective protection of the constitutional system is a foundational tenet of constitutional democratic thinking, ${ }^{122}$ and democratic constitutions are commonly understood as the embodiment of the will of the people. While certain powers and responsibilities may be allocated to various bodies or individuals, ubiquitous amendment procedures exemplify one mechanism for ensuring the constitution represents the changing will of the people, and effectively un-

120. Id. at 685 .

121. Id. at 690 .

122. See, e.g., KRAmer, supra note 107, at 199 ("The Supreme Court is not the highest authority in the land on constitutional law. We are."). 
dercut any representation of the judiciary as constitutional guardian. In a democratic constitutional state, should the people or the people's representatives decide that certain constitutional entities are not functioning properly, they can amend such provisions. While certain jurisdictions allocate to the judiciary the power of determining whether amendments are in fact constitutional, ${ }^{123}$ no constitution allows the judiciary, or even an all-powerful constitutional court, to have unilateral constitutional amendment powers. Also, in most jurisdictions, the judiciary does not have the power to decide which rights to enforce. ${ }^{124}$ Instead, courts must adhere to the constitution or a bill of rights. ${ }^{125}$ The constitutional amendment process may alter the substantive rights protected, but it is not for the judiciary to direct such changes except in their roles as private citizens. Ultimately, a state's citizens or representatives retain the power to formally amend the constitution, and thereby challenge the representation of the judiciary as constitutional guardian.

Despite these structural embodiments of the peoples' primacy, guardianship language has the potential to dilute the citizens' understanding of their own responsibility. If citizens do not take their responsibility seriously, but instead become overly-reliant on the judiciary to enforce and uphold constitutional values or norms, then society will unduly empower a purely judicial interpretation of the constitution at the cost of losing the perspective of its most important benefactors. When this overreliance on the judiciary becomes the norm, constitutional paternalism by the courts inevitably develops. The legal significance of the term guardian is therefore highly relevant.

Although commonly used to refer to "[a] person who protects or defends something,"126 the word guardian has a long

123. Yaniv Roznai, Unconstitutional Constitutional Amendments-The Migration and Success of a Constitutional Idea, 61 Aм. J. Comp. L. 657, 715-16 (2013).

124. And even if the courts do have such wide powers of interpretation, they are unlikely to formally admit this. Thus, any type of constitutional review is often explicitly connected to an articulated constitutional power.

125. Of course, the vagueness with which some of these constitutions or bills of rights are written give the judiciary significant leeway in determining what to enforce. Australia, which is examined throughout this paper, remains one of the few countries that still lacks an official bill of rights.

126. Guardian, OxFORD Dictionaries, https://en.oxforddictionaries.com /definition/guardian (last visited Mar. 4, 2019). 
and distinguished history in law. The Oxford Dictionary of Law states that "guardian" means, "[o]ne who is formally appointed to look after a child's interests on the death of the child's parents. . . . A guardian automatically has parental responsibility for the child." 127 Importantly, legal guardianship is not limited to children. The law may also subject adults with mental illness or mental capacity issues to some type of guardianship. ${ }^{128}$ Ultimately, this type of guardianship provides the guardian with the right to make decisions for those under their responsibility. ${ }^{129}$ With decision-making authority, the guardian gains power. This legal conception of guardian is undoubtedly more paternalistic than the general use of the term as one that protects or defends particular constitutional principles.

Understanding how the courts view their guardian role is therefore essential to understanding the significance of the designation. If the courts understand their guardianship role as a general responsibility to protect and defend, there is greater space for participation by other actors towards that collective end. Under this approach, the court would understand its role in the broader separation of powers framework, or perhaps even with a modern departmentalist role. ${ }^{130}$ If, on the other hand, the courts understand their guardianship role more like the singular overarching legal responsibility, they are more likely to assume sole decision-making authority.

Evidence suggests this legalistic understanding is dominant in many jurisdictions. In the New South Wales decision discussed above, the Australian High Court boldly asked: "[i]f

127. A Dictionary of Law 246-47 (6th ed. 2006).

128. For example, in the UK under the Mental Health Act 1983 "guardianship orders" can be given for those suffering for mental disorders. (Mental Health Act 1983 c. 20, s 37).

129. Interestingly, this type of guardianship is sometimes mentioned in constitutions. For example, the Fiji Constitution notes in s. 11(3) that, "Every person has the right to freedom from scientific or medical treatment or procedures without an order of the court or without his or her informed consent, or if he or she is incapable of giving informed consent, without the informed consent of a lawful guardian." (Fiji Const., s 11(3)).

130. For a view on departmentalism, see Robert Post \& Reva Siegel, Popular Constitutionalism, Departmentalism, and Judicial Supremacy, 92 CAL. L. REv. 1027, 1031 (2004) (The authors describe departmentalism as "the view that each of the three branches of the federal government possesses independent and coordinate authority to interpret the Constitution."). 
this Court does not fulfil its protective role under the Constitution, what other governmental institution will do so? What other institution has the power and the will to do so?"131 This assertive statement suggests the Court sees itself as better positioned and more committed to guard the constitution than any other branch or institution, and suggests a more legal conception of its guardian role.

Similarly, the Canadian Supreme Court identified three constitutional principles as positively within the legal sphere: legality, constitutionality, and rule of law. ${ }^{132}$ They further noted that the Constitution "demands that courts be empowered to protect its substance and uphold its promises." 133 This language asserts that the judiciary, as opposed to a collection of branches or citizens, is ultimately responsible for certain constitutional decisions. Finally, Justice Barak's holding in Israel's landmark Bank Mizrahi case describes judicial review as the "soul" of the constitution and asserts that judicial review alone can articulate the constitution's values. ${ }^{134}$ This insists that judicial decision-making power address problems in a manner reflecting the legalistic understanding of the guardianship role.

These examples contrast with the approach taken by U.K. courts, which show little willingness to explicitly assert themselves as guardians over the United Kingdom's long-standing unwritten constitution. The U.K. approach to the role of the courts is, accordingly, less paternalistic and more collective. Outside of official legal judgments, however, some members of the judiciary seem more willing to broach the idea of constitutional guardianship, ${ }^{135}$ and the UKSC shows more willingness to articulate specific constitutional principles under their purview. The U.K. approach is less in-line with the legal form of guardianship, and more focused on the protecting and defending nature of guardianship. Nevertheless, given the wide remit of the judiciary under the HRA 1998 and the wider ac-

131. NSWv Commonwealth, (2006) 229 CLR 1, 210.

132. Manitoba Métis Federation Inc. v. Canada, [2013] 1 S.C.R. 623, 685.

133. Id. at 690 .

134. CA 6821/93 United Mizrahi Bank Ltd. v. Midgal Cooperative Village 49(4) PD 221, para. 81 (1995) (Isr.).

135. Brian Christopher Jones, Dissonant Constitutionalism and Lady Hale, 29 KiNG's L.J. 177, 182-83 (2018). 
\begin{tabular}{lllll}
\hline |liprod01〉productnLNNYN51-3WNYI302.txt & unknown & Seq: 33 & 23-MAY-19 & 8:30 \\
\hline
\end{tabular}

ceptance of courts as ultimate constitutional guardians, changes could be on the horizon.

\section{Conclusion}

Although we might find comfort in believing that the twenty-first century will be as kind to democracy as the twentieth, the historical record tells us that democracy has been rare to human experience. Is it destined once again to be replaced by non-democratic systems, perhaps appearing in some twenty-first century version of Guardianship . . . ? ${ }^{136}$

Almost two decades into the twenty-first century, Robert Dahl's prediction appears to be taking form: unelected judges in apex courts throughout the world are increasingly viewed as the guardians of their respective constitutions. As judiciaries and other constitutional actors increasingly use factional constitutional guardian language as a means of expanding judicial power, a form of constitutional paternalism has emerged throughout many jurisdictions. There has been a significant rise in the use of guardian language on multiple fronts: in constitutions, in legal judgments, in academic writings, and throughout various media outlets. Based on the statistics provided above, this appears to be a relatively recent phenomenon. Although discussion around the idea of state guardianship started with Plato's Republic, and language of constitutional guardianship has been present since the founding of the United States, this language did not gain major traction until the late twentieth century. Such language arose without much consideration as to its specific meaning, including the potential effects on those within the constitutional state. Normatively, most constitutions do not formally label guardians. Constitutions that do explicitly mention guardianship tend to conceal such language by putting it not front and center, but in the middle or latter portions of such documents, thus obscuring its prominence and relevance. In the judicial realm, guardian-esque language may be fuelling more factional and combative judgments. Further, the language of many judgments takes on a more legal conception of the term guardian, 
implying that something has gone wrong, and only the judiciary can fix it.

This increased use of guardian-esque language epitomizes what actors worldwide should not do in terms of policing constitutions. Its unnecessarily paternalistic qualities may lull citizens-who are in fact the ultimate guardians-into constitutional complacency. Additionally, the more that various entities, and especially the judiciary, assert guardianship over particular areas of a constitution, the more such assertions amount to little more than trivial power struggles as opposed to authentic attempts to protect certain constitutional powers or functions. Ultimately, as this guardian language is now commonplace within the constitutional state, citizens, lawmakers, and academics alike should strive to understand its relevance and potential effects. Constitutional guardianship, after all, is not something that should be taken for granted, especially when its collective status is crumbling. 